\title{
PENINGKATAN KOMPETENSI GURU DALAM RANGKA MEWUJUDKAN GURU YANG PROFESIONAL
}

\author{
Ibadullah Malawi \\ PGSD IKIP PGRI MADIUN \\ Ibadullahmalawi62@ikippgrimadiun.ac.id
}

\begin{abstract}
Teachers as professional educators are obliged to plan and excute learning process, to evaluate outcomes, to give advice, to train, to develop studies, to support school deveopment program and to develop professionalism. Among other criteria, professional teachers must master learning materials, develop educating learning process, have good personality and build commitment of students' learning skill. To make them competent in conducting all of those tasks, teachers must have ability to search for information from variety of resources and from research which they conduct to support their educating instruction.
\end{abstract}

Keywords: Teachers' Competence, Prefessional, Instruction, Professionalism Development

\begin{abstract}
Abstrak
Guru sebagai tenaga profesional bertugas merencanakan dan melaksanakan proses pembelajaran, menilian hasil pembelajaran, melakukan pembimbingan, dan pelatihan, melakukan penelitian, membantu pengembangan dan pengelolaan program sekolah serta mengembangkan profesionalitas. Adapun ciri-ciri guru profesional adalah menguasai substansi kanian yang mendalam, dapat melaksanakan pembelajaran yang mendidik, berkepribadian, dan memiliki komitmen dan perhatian terhadap perkembangan peserta didik. Usaha untuk dapat meningkatkan kompetensinya, guru perlu memiliki kemampuan untuk menggali informasi dan berbagai sumber termasuk dari sumber elektronik dan melakukan kajian atau penelitian untuk untuk menunjang pembelajaran yang mendidik.
\end{abstract}

Kata Kunci: Kompetensi Guru, Profesional, Pembelajaran, Pengembangan Profesionalitas 


\section{A. Pendahuluan}

Undang-undang Nomor 14 tahun 2005 tentang Guru dan Dosen pasal 1 ayat 2 menggariskan beberapa hal: pertama guru sebagai unsur pendidik merupakan tenaga profisional dan ilmuwan dengan tugas utama mentransformasikan, mengembangkan, dan menyebarluaskan ilmu pengetahuan, teknologi, dan seni melalui pendidikan, penelitian, dan pengabdian kepada masyarakat. Kedua guru wajib memiliki kualifaikasi akademik, kompetensi, sertifikat pendidik, serta sehat jasmani dan rohani, dan memenuhi kualifikasi lain yang dipersyaratkan satuan pendidikan tinggi tempat bertugas, serta memiliki kemampuan untuk mewujudkan tujuan pendidikan nasional (Pasal 45). Kualifikasi akademik minimal yang dimaksud adalah lulusan program sarjana.

Guru dalam melaksanakan tugas keprofesian, berkewajiban: (1) melaksanakan pendidikan, penelitian, dan pengabdian kepada masyarakat; (2) merencanakan, melaksanakan proses pembelajaran, serta menilai dan mengevaluasi hasil pembelajaran; (3) meningkatkan dan mengembangkan kualifikasi akademik dan kompetensi secara berkelanjutan sejalan dengan perkembangan ilmu pengetahuan, teknologi, dan seni; (4) bertindak objektif dan tidak diskriminatif atas dasar pertimbangan jenis kelamin, agama, suku, ras, kondisi fisik tertentu, atau latar belakang sosio-ekonomi peserta didik dalam pembelajaran; (5) menjunjung tinggi peraturan perundang-undangan, hukum, dan kode etik, serta nilai-nilai agama dan etika; dan (6) memelihara dan memupuk persatuan dan kesatuan bangsa (Pasal 60). Adapun kompetensi yang harus dilimiki oleh seorang guru adalah kompetensi pedagogik, kompetensi kepribadian, kompetensi sosial, dan kompetensi profesional (Pasal 69 ayat 2).

\section{B. Pembahasan}

\section{Penguasaan Kompetensi Guru Sebagai Profesi}

Menurut Vollmer dan Mills profesi adalah sebuah pekerjaan/jabatan yang memerlukan kemampuan intelektual khusus, yang diperoleh melalui kegiatan belajar dan pelatihan yang bertujuan untuk menguasai ketrampilan atau keahlian dalam melayani atau memberikan layanan pada orang lain, dengan memperoleh upah atau gaji dalam jumlah tertentu (Baedhowi, 2005). Demikian juga pendapat Djojonegoro (1988) menyatakan bahwa profesionalisme dalam suatu jabatan ditentukan oleh tiga faktor, yaitu: (1) memiliki keahlian khusus yang dipersiapkan oleh program pendidikan keahlian atau spesialisasi; (2) kemampuan untuk memperbaiki ketrampilan dan keahlian khusus yang dimiliki; dan (3) memperoleh penghasilan yang memadai sebagai imbalan terhadap keahlian yang dimiliki itu.

Guru sebagai jabatan profesional harus memiliki persyaratan seperi tersebut, yaitu telah menempuh pendidikan formal, mempunyai kemampuan dalam pembelajaran (merencanakan, melaksanakan dan mengevaluasi pembelajaran), dan memperoleh imbalan atau gaji di atas upah minimum yang diterima oleh jabatan non profesional. Adapun kompetensi bersifat kompleks dan merupakan satu kesatuan yang utuh yang menggambarkan potensi, pengetahuan, ketrampilan, sikap dan nilai, yang dimiliki seseorang yang terkait dengan profesi tertentu berkenaan dengan bagian-bagian yang dapat diaktualisasikan atau 
diwujudkan dalam bentuk tindakan atau kinerja untuk menjalankan profesi tersebut. Perry (1966) mendefinisikan kompetensi sebagai berikut:

A competency is a cluster of related knowledge, skill and attitude that affects a major part of one's job (a role or responsibility), that correlates with performance in the job, that can be measured against well-accepted standards, and can be improved via training and development.

Berdasarkan uraian di atas dapat disimpulkan bahwa unsur kompetensi berupa potensi, pengetahuan, keterampilan, sikap dan nilai belum dapat mewujudkan kompetensi tetapi masih perlu dilengkapi dengan kemampuan mengkoordinasikan unsur-unsur tersebut agar dapat diwujudkan dalam bentuk tindakan atau kinerja. Bentuk dan kualitas kinerja dapat dipengaruhi oleh faktor eksternal antara lain lingkungan atau iklim kerja dan tantangan atau tuntutan pekerjaan. Kualifikasi dan profesionalitas merupakan contoh bentuk perwujudan dari kompetensi yang dimiliki seseorang. Kompetensi itu juga bersifat personal, artinya bahwa penguasaan komponen-komponen oleh seseorang tidak dapat diharapkan akan menghasilkan tindakan yang sama untuk mengatasi suatu masalah dengan tindakan orang lain yang memiliki kompetensi yang sama.

Guru yang profesional harus memiliki ciri-ciri menguasai substansi kajian yang mendalam, dapat melaksanakan pembelajaran yang mendidik, berkepribadian, dan memiliki komitmen dan perhatian terhadap perkembangan peserta didik. Karena substansi kajian dan konteks pembelajaran selalu berkembang dan berubah menurut dimensi ruang dan waktu, guru dituntut untuk selalu meningkatkan kompetensinya. Untuk dapat meningkatkan kompetensinya, guru perlu memiliki kemampuan untuk menggali informasi dari berbagai sumber termasuk dari sumber elektronika dan melakukan kajian atau penelitian untuk menunjang pembelajaran yang mendidik.

Totalitas kompetensi mengandung unsur-unsur yang dapat ditampilkan dan yang tidak dapat ditampilkan. Unsur-unsur yang dapat ditampilkan perlu dirumuskan dalam bentuk indikator-indikator untuk mengukur tingkat pencapaiannya. Indikator-indikator kompetensi itu berisi indikator yang bersifat esensial atau indikator inti dari masing-masing unsur kompetensi. Indikator dalam perwujudan kompetensi ini berguna untuk mengembangkan alat penilaian dalam rangka mengukur tingkat pencapaian kompetensi. Unsur yang tidak ditampilkan secara eksplisit, diharapkan dapat memberikan dampak positif terhadap penciptaan lingkungan belajar yang kondusif, yang selanjutnya akan berdampak pula terhadap proses dan hasil pembelajaran. Berikut ini disajikan kompetensi guru seperti yang tertera dalam Undang-undang Nomor 14 Tahun 2005 tentang Guru dan Dosen pasal 69, yaitu:

a. Memiliki Kompetensi Pedagogik

1) Memahami karakteristik peserta didik; yaitu harus memahami peserta didik dengan memanfatkan prinsip-prinsip perkembangan kognitif, prinsip-prinsip kepribadian, dan mengidentifikasi bekal awal peserta didik;

2) Merancang pembelajaran; yaitu dapat menerapkan teori belajar dan pembelajaran, menentukan strategi pembelajaran berdasarkan karakteristik 
peserta didik yang ingin dicapai, dan menyusun rancangan pembelajaran berdasarkan strategi yang telah dipilih;

3) Melaksanakan pembelajaran, yaitu dapat menata sarana dan prasarana belajar yang akan dapat digunakan secara tepat guna, memanfaatkan sarana dan prasarana belajar yang tersedia dan dapat disediakan, memanfaatkan lingkungan sebagai sumber belajar, memotivasi peserta didik melakukan pembelajaran yang interaktif, menjelaskan materi perkuliahan, memfasilitasi peserta didik untuk melakukan berbagai kegiatan belajar, memberi penguatan (reinforcement ) dalam pembelajaran, dan memberikan kesempatan kepada peserta didik untuk merefleksikan pengalaman belajar yang telah dialaminya;

4) Melaksanakan evaluasi hasil belajar; yaitu dapat melaksanakan penilaian (asesmen) proses dan hasil belajar secara berkesinambungan dengan berbagai metode, menganalisis hasil penilaian proses dan hasil belajar untuk menentukan tingkat ketuntasan belajar (mastery level), menggunakan informasi ketuntasan belajar untuk merancang program remidi atau pengayaan (enrichment), memanfaatkan hasil penilaian pembelajaran untuk perbaikan kualitas program pembelajaran, seperti menentukan bagian-bagian pembelajaran yang memerlukan perbaikan, merancang langkah-langkah perbaikan pembelajaran, dan mengembangkan diri secara terus menerus dalam meningkatkan profesi sebagai guru.

b. Memiliki Kompetensi Kepribadian

Seorang guru harus memiliki kepribadian yang baik, yaitu:

1) Memiliki kepribadian yang mantap dan stabil, artinya mampu bertindak sesuai dengan norma hukun, menunjukkan perilaku yang baik, bertindak sesuai dengan norma sosial (seperti bertutur kata secara santun, berpenampilan 'fisik' secara sopan, berperilaku santun), menunjukkan diri sebagai seorang pendidik, komitmen terhadap tugas sebagai pendidik, memiliki konsistensi dalam bertindak sesuai dengan norma (taat dalam tata tertib, berdisiplin kerja);

2) Memiliki kepribadian dewasa, yaitu menampilkan kemandirian dalam bertindak sebagai pendidik, memiliki etos kerja sebagai pendidik (mau kerja keras, melaksanakan tugas secara bertanggung jawab, mengembangkan diri secara terus menerus sebagai pendidik, dan tidak putus asa);

3) Memiliki kepribadian arif, yaitu menampilkan tindakan yang didasarkan pada kemanfaatan peserta didik, lembaga, dan masyarakat, menunjukkan keterbukaan dalam berpikir dan bertindak (menerima kritik dan saran untuk perbaikan);

4) Memiliki kepribadian yang berwibawa, yaitu memiliki perilaku yang berpengaruh positif terhadap peserta didik, memiliki perilaku yang disegani dan dihormati oleh peserta didik, teman sejawat, dan masyarakat;

5) Memiliki akhlak mulia dan dapat menjadi teladan, yaitu bertindak sesuai dengan norma religius (imtaq, jujur, ikhlas, suka menolong), memiliki perilaku yang diteladani peserta didik (bertutur dan berperilaku sopan dan terpuji sehingga menjadi teladan bagi peserta didik). 
c. Memiliki Kompetensi Profesional

Sebagai seorang dosen maka harus memiliki kompetsnsi profesional, artinya menguasai materi ajar yang diajarkan secara luas dan mendalam. Disamping itu, harus mampu memahami struktur, konsep, dan metode keilmuan yang koheren dengan materi ajar, memahami hubungan konsep antar materi perkuliahan yang terkait, dan dapat menerapkan konsep-konsep keilmuan dalam kehidupan sehari-hari. Seorang dosen harus memiliki referensi yang cukup, apabila seorang dosen mewajibkan kepada mahasiswa untuk membaca dua buah buku, maka dosen harus lebih dari dua buku, disamping materi pendukungnya yang relevan.

d. Memiliki Kompetensi Sosial

1) Dapat berkomunuikasi secara efektif baik dengan peserta didik, sesama dosen, dan masyarakat. Dosen harus dapat mengkomunikasikan pesan, memaknai pesan secara lisan dan tertulis;

2) Dapat bergaul secara efektif, yaitu dapat bergaul dengan peserta didik, sesama dosen, dan masyarakat. Dosen harus dapat bekerja sama atas dasar prinsip saling menghormati, mengembangkan hubungan atas dasar prinsip keterbukaan, mengembangkan hubungan berasaskan asah, asih, dan asuh;

3) Dapat bekerja sama secara efektif dengan peserta didik, sesama dosen, dan masyarakat, yaitu bekerja sama atas dasar prinsip saling menghormati, bekerja sama atas dasar prinsip keterbuykaan, dan bekerja sama atas dasar prinsip saling memberi dan menerima.

Standar kompetensi guru ini dikembangkan secara utuh dari empat kompetensi utama, yaitu kompetensi pedagogik, kepribadian, sosial, dan profesional. Keempat kompetensi tersebut terintegrasi dalam kinerja guru. Standar kompetensi guru mencakup kompetensi inti guru yang dikembangkan menjadi kompetensi guru PAUD/TK/RA, guru kelas SD/MI, dan guru mata pelajaran pada SD/MI, SMP/MTs, SMA/MA, dan SMK/MAK (Peraturan Pemerintah Nomor 16 Tahun 2007 tentang Standar Kulifikasi Akademik dan Kompetensi Guru).

\section{Standar Kompetensi Guru Kelas SD/MI}

Berdasarkan PP Nomor 16 tahun 2007 bahwa Kualifikasi Akademik Guru SD/MI Guru pada SD/MI, atau bentuk lain yang sederajat, harus memiliki kualifikasi akademik pendidikan minimum diploma empat (D-IV) atau sarjana (S1) dalam bidang pendidikan SD/MI (D-IV/S1PGSD/PGMI) atau psikologi yang diperoleh dari program studi yang terakreditasi. Adapun standar kompetensi guru kelas SD/MI diuraikan pada Tabel 1.

Tabel 1 Standar Kompetensi Guru Kelas

\section{No. Kompetensi Inti Guru Kompetensi Guru Kelas SD/MI}

Kompetensi Paedagogik 


\begin{tabular}{|c|c|c|}
\hline No. & Kompetensi Inti Guru & Kompetensi Guru Kelas SD/MI \\
\hline 1 & $\begin{array}{l}\text { Menguasai karakteristik } \\
\text { peserta didik dari aspek } \\
\text { fisik, moral, sosial, } \\
\text { kultural, emosional, dan } \\
\text { intelektual. }\end{array}$ & $\begin{array}{l}\text { 1.1 Memahami karakteristik peserta didik usia sekolah } \\
\text { dasar yang berkaitan dengan aspek fisik, } \\
\text { intelektual, sosial-emosional, moral, spiritual, dan } \\
\text { latar belakang sosial-budaya. } \\
\text { 1.2 } \begin{array}{l}\text { Mengidentifikasi potensi peserta didik usia } \\
\text { sekolah dasar dalam lima mata pelajaran SD/MI. }\end{array} \\
\text { 1.3 } \begin{array}{l}\text { Mengidentifikasi kemampuan awal peserta didik } \\
\text { usia sekolah dasar dalam lima mata pelajaran }\end{array} \\
\text { SD/MI. } \\
\text { 1.4 } \begin{array}{l}\text { Mengidentifikasi kesulitan peserta belajar } \\
\text { usia sekolah dasar }\end{array}\end{array}$ \\
\hline 2. & $\begin{array}{l}\text { Menguasai teori belajar } \\
\text { dan prinsip-prinsip } \\
\text { pembelajaran yang } \\
\text { mendidik. }\end{array}$ & 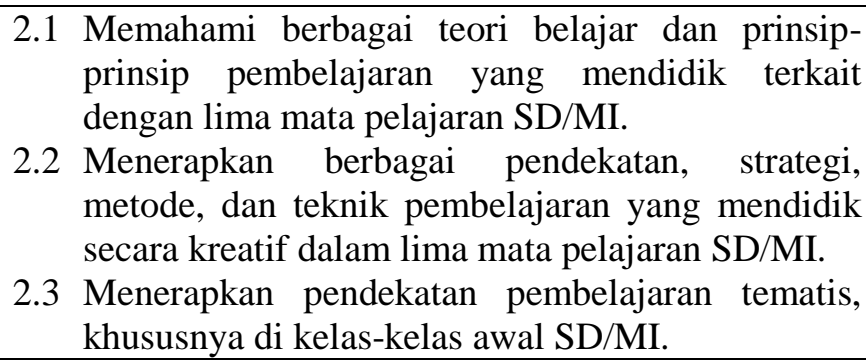 \\
\hline 3. & $\begin{array}{l}\text { Mengembangkan } \\
\text { kurikulum yang terkait } \\
\text { dengan mata pelajaran / } \\
\text { bidang pengembangan } \\
\text { yang diampu. }\end{array}$ & 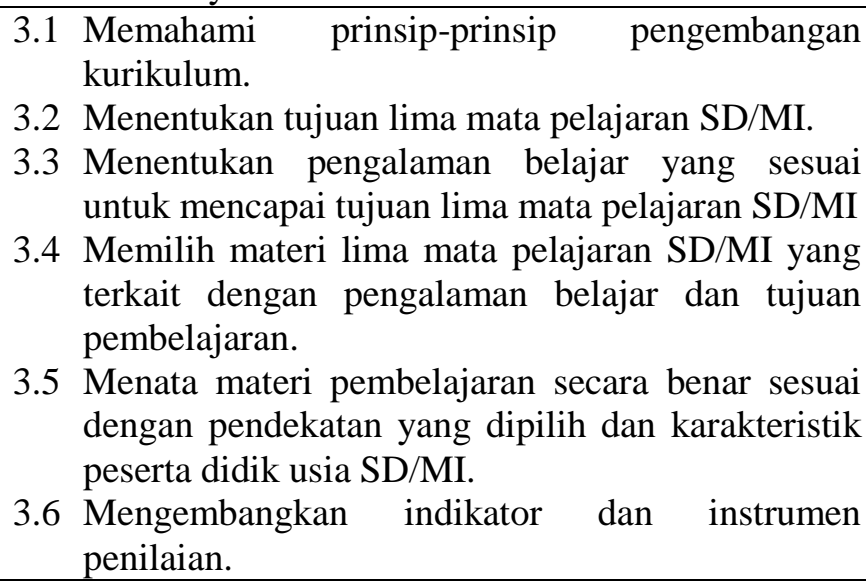 \\
\hline 4. & $\begin{array}{l}\text { Menyelenggarakan } \\
\text { pembelajaran yang } \\
\text { mendidik. }\end{array}$ & $\begin{array}{l}\text { 4.1 } \begin{array}{l}\text { Memahami prinsip-prinsip perancangan } \\
\text { pembelajaran yang mendidik. }\end{array} \\
\text { 4.2 } \begin{array}{l}\text { Mengembangkan komponen-komponen rancangan } \\
\text { pembelajaran. }\end{array} \\
\text { 4.3 } \begin{array}{l}\text { Menyusun rancangan pembelajaran yang lengkap, } \\
\text { baik untuk kegiatan di dalam kelas, laboratorium, } \\
\text { maupun lapangan. }\end{array} \\
\text { 4.4 } \begin{array}{l}\text { Melaksanakan pembelajaran yang mendidik di } \\
\text { kelas, di laboratorium, dan di lapangan. }\end{array} \\
4.5 \begin{array}{l}\text { Menggunakan media pembelajaran sesuai dengan } \\
\text { karakteristik peserta didik dan lima mata pelajaran }\end{array} \\
\text { SD/MI untuk mencapai tujuan pembelajaran } \\
\text { secara utuh. } \\
\text { 4.6 } \begin{array}{l}\text { Mengambil keputusan transaksional dalam lima } \\
\text { mata pelajaran SD/MI sesuai dengan situasi yang } \\
\text { berkembang. }\end{array}\end{array}$ \\
\hline
\end{tabular}




\begin{tabular}{|c|c|c|}
\hline No. & Kompetensi Inti Guru & Kompetensi Guru Kelas SD/MI \\
\hline 5. & $\begin{array}{l}\text { Memanfaatkan } \\
\text { teknologi informasi dan } \\
\text { komunikasi untuk } \\
\text { kepentingan } \\
\text { pembelajaran. }\end{array}$ & $\begin{array}{l}\text { 5.1 Memanfaatkan teknologi informasi dan } \\
\text { komunikasi dalam pembelajaran. }\end{array}$ \\
\hline 6. & $\begin{array}{l}\text { Memfasilitasi pengem- } \\
\text { bangan potensi peserta } \\
\text { didik untuk } \\
\text { mengaktualisasikan } \\
\text { berbagai potensi yang } \\
\text { dimiliki. }\end{array}$ & $\begin{array}{l}\text { 6.1 Menyediakan berbagai kegiatan pembelajaran } \\
\text { untuk mendorong peserta didik mencapai prestasi } \\
\text { belajar secara optimal. } \\
\text { 6.2 Menyediakan berbagai kegiatan pembelajaran } \\
\text { untuk mengaktualisasikan potensi peserta didik, } \\
\text { termasuk } \\
\text { kreativitasnya. }\end{array}$ \\
\hline 7. & $\begin{array}{l}\text { Berkomunikasi secara } \\
\text { efektif, empatik, dan } \\
\text { santun dengan peserta } \\
\text { didik. }\end{array}$ & $\begin{array}{l}\text { 7.1 Memahami berbagai strategi berkomunikasi yang } \\
\text { efektif, empatik dan santun, baik secara lisan } \\
\text { maupun tulisan. } \\
\text { 7.2 } \\
\text { Berkomunikasi secara efektif, empatik, dan santun } \\
\text { dengan peserta didik dengan bahasa yang khas } \\
\text { dalam interaksi pembelajaran yang terbangun } \\
\text { secara klasikal dari (a) penyiapan kondisi } \\
\text { psikologis peserta didik, (b) memberikan } \\
\text { pertanyaan atau tugas sebagai undangan kepada } \\
\text { peserta didik untuk merespons, (c) respons peserta } \\
\text { didik, (d) reaksi guru terhadap respons peserta } \\
\text { didik, dan seterusnya. }\end{array}$ \\
\hline 8. & $\begin{array}{l}\text { Menyelenggarakan } \\
\text { penilaian dan evaluasi } \\
\text { proses dan hasil belajar. }\end{array}$ & $\begin{array}{l}\text { 8.1 Memahami prinsip-prinsip penilaian dan evaluasi } \\
\text { proses dan hasil belajar sesuai dengan } \\
\text { karakteristik lima mata pelajaran SD/MI. } \\
\text { 8.2 Menentukan aspek-aspek proses dan hasil belajar } \\
\text { yang penting untuk dinilai dan dievaluasi sesuai } \\
\text { dengan karakteristik lima mata pelajaran SD/MI. } \\
\text { 8.3 } \begin{array}{l}\text { Menentukan prosedur penilaian dan evaluasi } \\
\text { proses dan hasil belajar. }\end{array} \\
\text { 8.4 } \begin{array}{l}\text { Mengembangkan instrumen penilaian dan evaluasi } \\
\text { proses dan hasil belajar. }\end{array} \\
\text { 8.5 } \begin{array}{l}\text { Mengadministrasikan penilaian proses dan hasil } \\
\text { belajar secara berkesinambungan dengan }\end{array} \\
\text { mengunakan berbagai instrumen. } \\
\text { 8.6 } \begin{array}{l}\text { Menganalisis hasil penilaian proses dan hasil } \\
\text { belajar untuk berbagai tujuan. }\end{array} \\
\text { 8.7 Melakukan evaluasi proses dan hasil belajar. }\end{array}$ \\
\hline 9. & $\begin{array}{l}\text { Memanfaatkan hasil } \\
\text { penilaian dan evaluasi } \\
\text { untuk kepentingan } \\
\text { pembelajaran. }\end{array}$ & $\begin{array}{l}\text { 9.1 Menggunakan informasi hasil penilaian dan } \\
\text { evaluasi untuk menentukan ketuntasan belajar. } \\
\text { 9.2 Menggunakan informasi hasil penilaian dan } \\
\text { evaluasi untuk merancang program remedial dan } \\
\text { pengayaan. } \\
\text { 9.3 Mengkomunikasikan hasil penilaian dan evaluasi } \\
\text { kepada pemangku kepentingan. } \\
\text { 9.4 Memanfaatkan informasi hasil penilaian dan }\end{array}$ \\
\hline
\end{tabular}




\begin{tabular}{llrl}
\hline No. & Kompetensi Inti Guru & Kompetensi Guru Kelas SD/MI \\
\hline & & $\begin{array}{l}\text { evaluasi pembelajaran untuk meningkatkan } \\
\text { kualitas pembelajaran. }\end{array}$ \\
\hline $\begin{array}{l}\text { 10. } \\
\text { Melakukan } \\
\text { reflektif } \\
\text { peningkatan } \\
\text { pembelajaran. }\end{array}$ & $\begin{array}{c}\text { tindakan } \\
\text { untuk }\end{array}$ & $\begin{array}{l}\text { kelakukan refleksi terhadap pembelajaran yang } \\
\text { telah dilaksanakan. }\end{array}$ \\
& $10.2 \begin{array}{l}\text { Memanfaatkan hasil refleksi untuk perbaikan dan } \\
\text { pengembangan lima mata pelajaran SD/MI. } \\
\end{array}$ & $10.3 \begin{array}{l}\text { Melakukan penelitian tindakan kelas untuk } \\
\text { meningkatkan kualitas pembelajaran lima mata } \\
\text { pelajaran SD/MI. }\end{array}$ \\
\hline
\end{tabular}

\begin{tabular}{ll}
\hline Kompetensi Kepribadian \\
\hline 11. & Bertindak sesuai dengan \\
norma agama, hukum, \\
sosial, dan kebudayaan \\
nasional Indonesia.
\end{tabular}

11.1 Menghargai peserta didik tanpa membedakan keyakinan yang dianut, suku, adat-istiadat, daerah asal, dan gender.

11.2 Bersikap sesuai dengan norma agama yang dianut, hukum dan norma sosial yang berlaku dalam masyarakat, serta kebudayaan nasional Indonesia yang beragam.

12. Menampilkan diri 12.1 Berperilaku jujur, tegas, dan manusiawi. sebagai pribadi yang 12.2 Berperilaku yang mencerminkan ketakwaan dan jujur, berakhlak mulia, akhlak mulia.

dan teladan bagi peserta 12.3 Berperilaku yang dapat diteladani oleh peserta didik dan masyarakat. didik dan anggota masyarakat di sekitarnya.

13. Menampilkan diri 13.1 Menampilkan diri sebagai pribadi yang mantap sebagai pribadi yang dan stabil.

mantap, stabil, dewasa, 13.2 Menampilkan diri sebagai pribadi yang dewasa, arif, dan berwibawa. arif, dan berwibawa.

14. Menunjukkan etos 14.1 Menunjukkan etos kerja dan tanggung jawab kerja, tanggung jawab yang tinggi.

yang tinggi, rasa bangga 14.2 Bangga menjadi guru dan percaya pada diri menjadi guru, dan rasa percaya diri. sendiri.

14.3 Bekerja mandiri secara profesional.

15. Menjunjung tinggi kode 15.1 Memahami kode etik profesi guru.

etik profesi guru. $\quad 15.2$ Menerapkan kode etik profesi guru.

15.3 Berperilaku sesuai dengan kode etik guru.

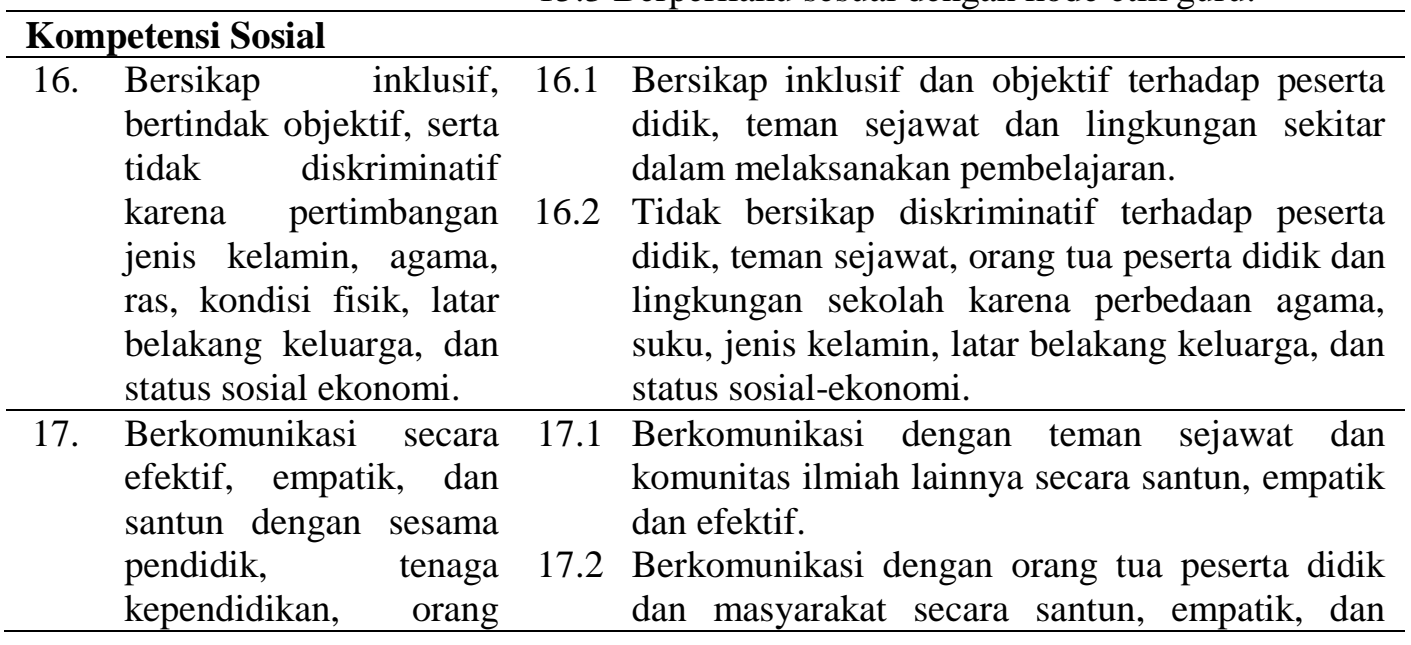




\section{No. Kompetensi Inti Guru Kompetensi Guru Kelas SD/MI \\ tua, dan masyarakat. $\quad$ efektif tentang program pembelajaran dan kemajuan peserta didik. \\ 17.3 Mengikutsertakan orang tua peserta didik dan masyarakat dalam program pembelajaran dan dalam mengatasi kesulitan belajar peserta didik.

\begin{tabular}{llrr}
\hline 18. & Beradaptasi di tempat & 18.1 & Beradaptasi dengan lingkungan tempat bekerja \\
bertugas di & seluruh & & dalam rangka meningkatkan efektivitas sebagai \\
wilayah & Republik & & pendidik, termasuk memahami bahasa daerah \\
Indonesia & yang & & setempat.
\end{tabular}

memiliki keragaman 18.2 Melaksanakan berbagai program dalam sosial budaya. meningkatkan kualitas pendidikan di daerah yang bersangkutan.

19. Berkomunikasi dengan 19.1 Berkomunikasi dengan teman sejawat, profesi komunitas profesi sendiri dan profesi lain secara lisan dan tulisan atau bentuk lain. ilmiah, dan komunitas ilmiah lainnya melalui berbagai media dalam rangka meningkatkan kualitas pendidikan.

19.2 Mengkomunikasikan hasil-hasil inovasi pembelajaran kepada komunitas profesi sendiri secara lisan dan tulisan atau bentuk lain.

\begin{tabular}{|c|c|c|}
\hline \multicolumn{3}{|l|}{ Kompetensi Profesional } \\
\hline \multirow{11}{*}{$\begin{array}{l}\text { 20. Menguasai materi, } \\
\text { struktur, konsep, dan } \\
\text { pola pikir keilmuan } \\
\text { yang mendukung mata } \\
\text { pelajaran yang diampu. }\end{array}$} & \multirow{3}{*}{\multicolumn{2}{|c|}{$\begin{array}{l}\text { Bahasa Indonesia } \\
20.1 \text { Memahami hakikat bahasa dan pemerolehan } \\
\text { bahasa. } \\
20.2 \begin{array}{l}\text { Memahami kedudukan fungsi, dan ragam } \\
\text { bahasa Indonesia. }\end{array}\end{array}$}} \\
\hline & & \\
\hline & & \\
\hline & & $\begin{array}{l}\text { Menguasai dasar-dasar dan kaidah bahasa } \\
\text { Indonesia sebagai rujukan penggunaan bahasa } \\
\text { Indonesia yang baik dan benar. }\end{array}$ \\
\hline & & $\begin{array}{l}\text { Memiliki keterampilan berbahasa Indonesia } \\
\text { (menyimak, berbicara, membaca, dan menulis). }\end{array}$ \\
\hline & 20.5 & Memahami teori dan genre sastra Indonesia. \\
\hline & 20.6 & $\begin{array}{l}\text { Mampu mengapresiasi karya sastra Indonesia, } \\
\text { secara reseptif dan produktif. }\end{array}$ \\
\hline & \multicolumn{2}{|c|}{ Matematika } \\
\hline & 20.7 & $\begin{array}{l}\text { Menguasai pengetahuan konseptual dan } \\
\text { prosedural serta keterkaitan keduanya dalam } \\
\text { konteks materi aritmatika, aljabar, geometri, } \\
\text { trigonometri, pengukuran, statistika, dan logika } \\
\text { matematika. }\end{array}$ \\
\hline & 20.8 & $\begin{array}{l}\text { Mampu menggunakan matematisasi horizontal } \\
\text { dan vertikal untuk menyelesaikan masalah } \\
\text { matematika dan masalah dalam dunia nyata. }\end{array}$ \\
\hline & 20.9 & $\begin{array}{l}\text { Mampu menggunakan pengetahuan konseptual, } \\
\text { prosedural, dan keterkaitan keduanya dalam } \\
\text { pemecahan masalah matematika, serta. } \\
\text { penerapannya dalam kehidupan sehari-hari. }\end{array}$ \\
\hline
\end{tabular}




\section{No. Kompetensi Inti Guru Kompetensi Guru Kelas SD/MI \\ 20.10 Mampu menggunakan alat peraga, alat ukur, alat hitung, dan piranti lunak komputer.}

IPA

20.11.Mampu melakukan observasi gejala alam baik secara langsung maupun tidaklangsung.

20.12.Memanfaatkan konsep-konsep dan hukumhukum ilmu pengetahuan alam dalam berbagai situasi kehidupan sehari-hari.

20.13.Memahami struktur ilmu pengetahuan alam, termasuk hubungan fungsional antarkonsep, yang berhubungan dengan mata pelajaran IPA.

IPS

20.14 Menguasai materi keilmuan yang meliputi dimensi pengetahuan, nilai, dan keterampilan IPS.

20.15 Mengembangkan materi, struktur, dan konsep keilmuan IPS.

20.16 Memahami cita-cita, nilai, konsep, dan prinsipprinsip pokok ilmu-ilmu sosial dalam konteks kebhinnekaan masyarakat Indonesia dan dinamika kehidupan global.

20.17 Memahami fenomena interaksi perkembangan ilmu pengetahuan, teknologi, seni, kehidupan agama, dan perkembangan masyarakat serta saling ketergantungan global.

PKn

20.18 Menguasai materi keilmuan yang meliputi dimensi pengetahuan, sikap, nilai, dan perilaku yang mendukung kegiatan pembelajaran PKn.

20.19 Menguasai konsep dan prinsip kepribadian nasional dan demokrasi konstitusional Indonesia, semangat kebangsaan dan cinta tanah air serta bela negara.

20.20 Menguasai konsep dan prinsip perlindungan, pemajuan HAM, serta penegakan hukum secara adil dan benar.

20.21 Menguasai konsep, prinsip, nilai, moral, dan norma kewarganegaraan Indonesia yang demokratis dalam konteks kewargaan negara dan dunia.

\begin{tabular}{llrlrrr}
\hline 21. & $\begin{array}{l}\text { Menguasai } \\
\text { kompetensi }\end{array}$ & dandar & 21.1 & $\begin{array}{l}\text { Memahami standar kompetensi lima } \\
\text { pelajaran SD/MI. }\end{array}$ & mata \\
$\begin{array}{l}\text { kompetensi dasar mata } \\
\text { pelajaran/bidang }\end{array}$ & 21.2 & $\begin{array}{l}\text { Memahami kompetensi dasar } \\
\text { pelajaran SD/MI. }\end{array}$ & lima mata \\
$\begin{array}{l}\text { pengembangan } \\
\text { diampu. }\end{array}$ & yang & 21.3 & $\begin{array}{l}\text { Memahami tujuan pembelajaran lima } \\
\text { pelajaran SD/MI. }\end{array}$ & & mata \\
\hline
\end{tabular}




\begin{tabular}{|c|c|c|}
\hline No. & Kompetensi Inti Guru & Kompetensi Guru Kelas SD/MI \\
\hline 22. & $\begin{array}{l}\text { Mengembangkan materi } \\
\text { pembelajaran yang } \\
\text { diampu secara kreatif. }\end{array}$ & $\begin{array}{l}\text { 22.1 } \begin{array}{l}\text { Memilih materi lima mata pelajaran SD/MI yang } \\
\text { sesuai dengan tingkat perkembangan peserta } \\
\text { didik. }\end{array} \\
\text { 22.2 } \\
\text { Mengolah materi lima mata pelajaran SD/MI } \\
\text { secara integratif dan kreatif sesuai dengan } \\
\text { tingkat perkembangan peserta didik. }\end{array}$ \\
\hline 23. & $\begin{array}{l}\text { Mengembangkan } \\
\text { keprofesionalan secara } \\
\text { berkelanjutan dengan } \\
\text { melakukan tindakan } \\
\text { reflektif. }\end{array}$ & $\begin{array}{ll}\text { 23.1 } & \begin{array}{l}\text { Melakukan refleksi terhadap kinerja sendiri } \\
\text { secaral terus menerus. }\end{array} \\
\text { 23.2 } & \begin{array}{l}\text { Memanfaatkan hasil refleksi dalam rangka } \\
\text { peningkatan keprofesionalan. }\end{array} \\
\text { 23.3 } & \begin{array}{l}\text { Melakukan penelitian tindakan kelas untuk } \\
\text { peningkatan keprofesionalan. }\end{array} \\
\text { 23.4 } & \begin{array}{l}\text { Mengikuti kemajuan zaman dengan belajar dari } \\
\text { berbagai sumber. }\end{array} \\
\end{array}$ \\
\hline 24 & $\begin{array}{l}\text { Memanfaatkan } \\
\text { teknologi informasi dan } \\
\text { komunikasi untuk } \\
\text { berkomunikasi dan } \\
\text { mengembangkan diri. }\end{array}$ & $\begin{array}{lll}\text { 24.1 Memanfaatkan teknologi informasi } & \text { dan } \\
& \text { komunikasi dalam berkomunikasi. } \\
\text { 24.2 } & \begin{array}{l}\text { Memanfaatkan teknologi informasi } \\
\text { komunikasi untuk pengembangan diri. }\end{array} & \\
\end{array}$ \\
\hline
\end{tabular}

\section{Implikasi terhadap Lembaga Pengadaan Tenaga Kependidikan}

Lembaga Pengadaan Tenaga Kependidikan (LPTK) sebagai lembaga pencetak calon guru, dimana seorang guru yang profesional juga harus memiliki empat kompetensi yaitu kompetensi pedagogik, kompetensi kepribadian, kompetensi sosial, dan kompetensi profesional yang diperoleh melalui pendidikan profesi (Undang-undang Nomor 14 Tahun 2005 pasal 10 dan Peraturan Pemerintah Nomor 19 tahun 2005 pasal 28 ayat 3). Dengan adanya standar kompetensi guru tersebut membawa konsekuensi LPTK, yakni:

a. Kurikulum

Dalam pengembangan kurukulum, standar kompetensi menuntut diterapkannya pendekatan pengembangan kurikulum berbasis kompetensi. Dengan pendekatan tersebut, mata kuliah dikembangkan atas dasar jenis dan muatan pengalaman belajar yang diperlukan dalam pembentukan suatu kompetensi yang secara programatik dirancang untuk membangun profil utuh kompetensi lulusan. Oleh karena itu, beban sks (satuan kredit semester) mata kuliah ditentukan berdasarkan tuntutan pencapaian kompetensi yang secara programatik proporsional dengan ruang kurikulum yang tersedia untuk setiap strata.

Kurikulum yang dikembangkan berbasis dan bermuara pada pencapaian kompetensi menuntut pelaksanaan kurikulum yang memobilisasikan seluruh dimensi proses pembelajaran untuk menghasilkan pembentukan kompetensi dalam diri mahasiswa calon guru. Standar kompetensi juga berimplikasikan terhadap pemilihan materi perkuliahan. Konsep atau bahan kajian yang esensial dan strategis perlu dipilih sesuai dengan waktu dan ruang kurikulum untuk mendukung pencapaian kompetensi atau indikator kompetensi. Dengan kata lain, jumlah mata kuliah dan bahan kajian yang dipilih sedemikian rupa sehingga dapat 
dikelola dalam pembelajaran untuk mengembangkan kompetensi peserta didik yang direncanakan. Keluasan dan kedalaman materi juga perlu diperhatkan sehingga lulusan dapat memiliki keyakinan/kepercayaan pada dirinya dan kemantapan dalam mendidik, mengajar, membina dan melatih peserta didiknya di kemudian hari. Disamping itu, beban mengajar mata kuliah dari masing-masing dosen juga harus dipertimbangkan. Apabila seorang dosen memegang empat sampai lima mata kuliah, bagaimana mungkin akan dapat mengembangkan materi secara mendalam (belum tugas-tugas yang lain seperti penelitian, pengabdian masyarakat, proyek, dan panitia).

\section{b. Pelaksanaan Pembelajaran}

Pembelajaran sebagai proses pengembangan kompetensi diwujudkan dalam model pembelajaran yang menggunakan pendekatan dan metode pembelajaran yang menddik. Aktivitas pembelajaran mencerminkan kualitas pembekelan pencapaian kompetensi mahasiswa calon guru. Beberapa kondisi pembelajaran yang dapat mendudkun pencapaian kompetensi adalah: (1) mengenalkan pengelolaan kelembagaan, khususnya sekolah dalam jenjang pendidikan dasar dan menengah; (2) memanfaatkan hasil-hasil penelitian dan kajian konseptual untuk peningkatan kualitas pembelajaran; (3) mengembangkan proses pembelajaran berbasis aktivitas mahasiswa dengan latar kegiatan dunia kerja; dan (4) merumuskan indikator secara jelas pencapaian kompetensi selama satuan waktu perkuliahan (Sofyan, 2005).

Pembelajaran yang perlu dikembangkan oleh guru dalam rangka pembentukan kompetensi adalah interaksi yang memungkinkan para mahasiswa mampu membangun pengetahuan, sikap, dan keterampilannya melalui berbagai modus transformasi pengelaman belajar. Proses tersebut dibingkai oleh skenario pembelajaran yang mendidik, mencerdaskan yang didasarkan pada moral agama, membudayakan dan memberdayakan peserta didik. Karena itu, pengembangan kurikulum program studi di LPTK perlu berorientasi pada dunia kerja, sedangkan pembelajarannya berorientasi pada siswa atau cara belajar mahasiswa aktif.

Selain pembelajaran perlu direncanakan dan dilaksanakan sesuai dengan pembelajaran yang dibutuhkan bagi calon guru, standar kompetensi juga berimplikasikan pada penyediaan sarana dan prasarana pembelajaran, termasuk media, sumber belajar, berbagai fasilitas praktikum yang memungkinkan peserta didik memperoleh pengalaman belajar secara konkrit, luas, dan mendalam.

Guru sebagai pendidik dan berkedudukan sebagai unsur utama dalam menerapkan kurikulum, perlu dikembangkan pengetahuan, sikap dan keterampilan profesionalnya agar mampu memfasilitasi proses belajar mahasswa yang diorientasikan pada terbentuknya kompetensi profesional calon guru. Setiap pendidik calon guru harus dapat merencanakan dan melaksanakan pembelajaran yang interaktif, yang memungkinkan para mahasiswa mampu membangun pengetahuan, sikap, dan ketarmpilannya serta kepribadiannya melalui transformasi pengalaman. Proses tersebut dibingkai oleh skenario pembelajaran yang mendidik, mencerdaskan mahasiswa dalam kerangka nilai dan moral yang baik dan membudaya. 
c. Asesmen Pembelajaran

Pendekatan, metode, dan pelaksanaan asesmen yang sistematik, sistematis, dan mengacu pada standar kompetensi yang telah ditetapkan diperlukan untuk mengases pencapaian pembentukan kompetensi calon guru. Karena itu penerapan asesmen perlu mencakup asesmen diagnostik, asesmen refketif, asesmen formatif, asesmen sumatif dan asesmen akuntabilitas pada kurun waktu. Berbagai evaluasi tersebut harus selalu mengacu standar keterampilan profesional yang berlaku di dunia kerja. Asesmen yang sistemik dan sistematis tersebut sekaligus akan dapat mengkaji efisiensi dan efektivitas program pendidikan guru secara menyeluruh termasuk kehandalan program pendidikan guru yang menggunakan kurikulum berbasis kompetensi.

Asesmen proses dan hasil belajar peserta didik secara formatif dan secara diagnostik diperlukan untuk menyediakan pengalaman belajar secara mandiri dan secara kelompok sehingga setiap peserta didik dapat meningkatkan kemampuan untuk dapat belajar sepanjang hayat. Perencanaan dan pengembangan instrumen untuk melakukan asesmen terhadap proses dan hasil belajar peserta didik perlu mengarah pada sejauh mana tahapan pengalaman belajar dan tercapainya indikator butir-butir kompetensi yang telah direncanakan.

\section{d. Sarana dan Prasarana}

Sarana dan prasarana pendidikan merupakan komponen yang sangat menentukan efisiensi pencapaian kompetensi. Dalam menghadapi daya saing bangsa dan globalisasi, diperlukan pengembangan dan pemanfatan sarana pembelajaran yang memadai dan diperlukan jaringan. Bersamaan dengan itu, kemampuan dan keleluasaan civitas akademika LPTK untuk mengakses informasi perlu difasilitasi secara terprogram.

\section{e. Organisasi dan Manajemen}

Untuk mendukung keseluruhan upaya menghasilkan guru yang mengauasi kompetensi sebagaimana dituntut dalam standar kompetensi maka diperlukan organisasi dan managemen pendidikan guru yang harus dirancang untuk menjadi sarana pembentukan kompetsnsi guru secara utuh. Oraganiasasi yang perlu dikembangkan adalah organisasi yang dapat mendukung kebebasan akademik, menghargai inovasi dalam bidang pembelajaran dan evaluasi, kreativitas dosen untuk berbagi pengetahuan, memperhatikan jenjang karier dosen, mendorong tindakan yang bersifat proaktif, efektif dan efisien, dan bertanggung jawab dalam melaksanakan tugas.

Unsur manajemen yang perlu mendapat perhatian adalah rekrutmen dan penugasan dosen pembina dan pengasuh matakuliah, rekrutmen dan penugasan tenaga kependidikan lain yang menunjang pelaksanaan pendidikan, seperti laborat, teknisi, pustakawan, dan tenaga administrasi lain; sarana dan prasarana yang memfasilitasi pembentukan kompetensi guru seperti: perpustakaan, laboratorium microteaching, sekolah latihan; mitra industri, dan berbagai asosiasi profesi, serta sistem penjaminan kualitas yang antara lain menyangkut prosedur layanan baku dalam pengembangan bahan ajar, pembelajaran, pengujian, praktik pengalaman lapangan, dan uji kompensi dalam rangka sertifikasi. 


\section{f. Kendali Mutu}

Standar kompetensi merupakan acuan utama kendali mutu lulusan program studi pendidikan guru. Penjaminan mutu tercermin dalam proses pembelajaran dalam rangka pemenuhan standar mutu pengelolaan pendidikan LPTK. Upaya penjaminan mutu dilakukan secara konsisten dan berkelanjutan sejak dari peningkatan mutu masukan, pembelajaran yang variatif sampai dengan asesmen proses dan hasil belajar.

\section{g. Kerjasama/Kemitraan}

Pembentukan kompetensi guru merupakan proses pendidikan yang memerlukan keterlibatan dari berbagai pihak, seperti sekolah latihan, dunia kerja/industri, pemerintah daerah (dalam hal ini dinas pendidikan), dan berbagai asosiasi profesi. Untuk itu diperlukan adanya dan terpeliharanya jaringan kemitraan antara LPTK dan semua unsur tersebut. Kemitraan LPTK dengan sekolah-sekolah dengan berazazkan "keuntungan akademik" yang timbal balik sangat dieperlukan dalam meningkatkan mutu pendidikan di kedua belah pihak. Sekolah latihan sebenarnya juga diperlukan sebagai wahana sosio-pedagogis yang memungkinkan para mahasiswa calon guru mendapatkan pengalaman langsung dalam pelaksanaan pembelajaran.

Oleh karena itu diperlukan mitra, yang apabila dilihat dari berbagai makna yang dituntut cukup memadai sebagai sekolah latihan yang baik. Sedangkan mitra industri diperlukan sebagai wahana pengenalan terhadap dunia kerja, standar kerja, dan perkembangan teknologi mutakhir. Jaringan kerja dengan dunia industri atau dunia kerja perlu dikembangkan untuk membantu kelancaran dan keiuntungan akademik yang optimum. Sedangkan aspek kerjasama ini meliputi resorces sharing, problem solving, dan konsorsium.

\section{Penutup}

Sebagai usaha untuk meningkatkan kompetensi guru dalam rangka mewujudkan guru profesional, maka guru harus menguasai bidang studi yang diajarkan, yaitu: pertama penguasaan karakteristik dan substansi bidang studi yang diajarkan, pengembangan konsep bidang studi yang dipelajari, penguasaan keterkaitan konsep bidang studi yang diajarkan dengan konsep ilmu lain yang relevan, penguasaan bahan kajian bidang studi yang diajarkan dengan menyesuakan substansi bidang studi dengan tuntutan dalam ruang gerak kurikuler.

Kedua pemahaman tentang peserta ddik yaitu pemahaman karakteristik peserta didik dan tahapan perkembangannya dalam aspek intelektual, personal, spiritual dan sosial serta perananya dalam mengoptimalkan perkembangan dan pembelajaran peserta didik. Ketiga pengguasaan prinsip-prinsip dasar proses pendidikan dan pembelajaran serta penerapannya dalam perencanaan, pelaksanaan, penilaian dan pengembangan proses pembelajaran yang mendidik. Keempat pengembangan kepribadian yaitu pengembangan nilai-nilai kepribadian sebagai seorang pendidik yang memiliki akhlak mulia sesuai dengan normanorma agama dan masyarakat sehingga sebagai panutan peserta didik. 


\section{DAFTAR RUJUKAN}

Baedhowi. 2005. Langkah-langkah Strategis dalam Mewujudkan Guru Sebagai Profesi. Makalah disampaikan pada acara Temu Alumni FKIP UNS, Surakarta, 15 Januari.

Depdiknas. 2003. Kurikulum 2004: Kerangka Dasar. Jakarta: Departemen Pendidikan Nasional.

Depdiknas. 2004. Pedoman Pengembangan Sistem Asesmen Berbasis Kompetnsi. Jakarta: P2TK \& KPT.

Peraturan Pemerintah Nomor 16 Tahun 2007 tentang Standar Kulifikasi Akademik dan Kompetensi Guru. Jakarta: Depdiknas.

Peraturan Pemerintah Nomor 19 Tahun 2005 tentang Standar Nasional Pendidkan. Jakarta: Depdiknas.

Sofyan, H. 2005. Standar Kompetensi Guru. Makalah disampaikan pada Training Kompetensi Guru Mata Pelajaran UAN di Universitas Sebelas Maret, Surakarta, 25 s.d. 27 Agustus.

Undang-undang Republik Indonesia Nomor 14 Tahun 2005 tentang Guru dan Dosen. Jakarta: Depdiknas.

Undang-undang Republik Indonesia Nomor 20 Tahun 2003 tentang Sistem Pendidikan Nasional. Jakarta: Depdiknas. 